\title{
THE ROLE OF ACTIVATED CARBON IN SOLVING ECOLOGICAL PROBLEMS
}

\author{
V. M. Mukhin ${ }^{\mathrm{a}}$ T. G. Lupascu \\ ${ }^{a}$ OJSC “NPO “Neorganika”, Electrostal, Moscow region. \\ ${ }^{b}$ Institute of Chemistry of the Academy of Sciences of Moldova
}

\begin{abstract}
The authors present a brief analysis of the current global situation concerning the utilization of activated carbon in various fields. The article presents data concerning the synthesis and adsorption and structure properties of new activated carbons, used for solving ecological problems. The authors investigated the newly obtained activated carbons in comparison with several AC marks known in the world. It has been shown that currently synthesized AC are competitive with foreign marks.
\end{abstract}

Keywords: activated carbon, precious metals, environment.

The end of the so-called era of "cold war" was called forth significantly by the fact that the fear of an ecological bomb detonating overwhelmed the hearts of people. The sudden increase of the rate of environmental pollution began to bring such harm to mankind that it could be compared with the use of WMD including chemical weaponry.

According to the information provided by the WHO (2002) the state of health of an individual depends on: $51 \%$ of the way of life, $39 \%$ of the environment, and $10 \%$ of the quality of medical treatment.

The analysis initiated in 1945 showed that casualties of military conflicts during the period from 1945 till 1993 came to 23 million people of military personnel AND civilians. In the mean time, during the same period, approximately 150 million people became victims of malaria, tuberculosis, AIDS, and other diseases. This shows how vital a clean environment is, an environment where contagious diseases have no ability to spread.

Therefore, in the twenty first century mankind has entered a new age - age of environmental protection, where the key role in purification of industrial discharges is assigned to carbon-adsorbing technologies.

On the other hand, activated carbons allow us to perform a variety of tasks in industries, power engineering, agriculture, oil and gas refinement, etc.

At present, fields of application of adsorption technologies based on activated carbons (AC for short) are developing at a great pace. This is due to three main reasons: firstly, activated carbons allow solving the most burning issues of protecting the environment against industrial discharges, secondly - preserve high cleanness of substances, materials, and products, and thirdly - contribute to implementation of high technologies of production.

Ecological activated carbon utilizing technologies of global importance.

\begin{tabular}{|l|l|}
\hline \multicolumn{1}{|c|}{ Component of biosphere } & \multicolumn{1}{c|}{ Carbon-adsorption technology } \\
\hline Atmosphere & Recuperation of solvents \\
& $\begin{array}{l}\text { Purification of gases of combustion, including desulfurization } \\
\text { Gas fumes trapping }\end{array}$ \\
& Chemical weaponry disposal \\
Incoming air cleaning (air conditioning) [1,2]
\end{tabular}

In the USSR during the most favourable 1985-88 years 38k tons of AC were produced each year, comprising $85 \%$ coal based AC (AG and AR types), $2 \%$ peat based AC (SKT type), and 13\% wood based AC (BAU type). 
In Russia, the main source of raw materials for production of carbon sorbents remains to be rock carbon material of different stages of metamorphism (from lignite to anthracite), main deposits of which are concentrated in the Kuznetsk Basin.

In the republic of Moldova, the main raw material for AC obtaining is represented by the secondary materials resulted after processing agricultural materials, such as: stones of peaches, prunes and apricots, grape seeds and nuts shells. According to data presented by the officials in this area, Moldova needs annually around 240 tons of AC, mainly for potabilization of surface and underground water (180 t), food industry (50 t) and for health protection (10t) [4].

In order to develop new technologies of producing AC, fulfilment of two major goals is required. These are: conversion of currently running developments and construction of new enterprises connected to sources of materials.

Let us discuss in detail the most vital directions of carbon-adsorption technologies' development.

Environment pollution created by motor transport is constantly growing, thus cars are to be equipped with gastrapping systems (GTS) in accordance with the "EURO" standards. A GTS represents an adsorber filled with AC.

On the basis of coal half-coke of Leninsk-Kuznetskiy factory of coking, an adsorber for GTS with USK-DB mark rational pore structure has been developed. The adsorber had petrol fumes desorption value about $40 \%$ higher than its foreign analogues. It was later modified and reconstructed as annular cylindrical unit. At the moment, the full quantity of GTS developed is $800 \mathrm{k}$ pieces with worth estimated as 220 million rubles, as a result they have caught nearly $7 \mathrm{k}$ tons of petrol.

It is known that from 35 to $40 \%$ of the world's AC production are dedicated to drinking water supply; moreover, its deployment is essential in emergency situations (e.g. nitrophenol contamination of river Amur in December 2005).

SS coal mark of Belovskoy open-pit mine was used as a basis for the technology of producing "Hydrosorb" mark AC, which is used for ozone-sorption drinking water purification. It was successfully implemented in 2002 at Rublyovskaya waterworks (RW) in Moscow (the extent of implementation was 1500 tons).

The water quality control data, taken after three years of the fourth bloc being operational ( $240 \mathrm{k} \mathrm{m}^{3}$ per day), was compared to the original structures of the RW. According to the data the effectiveness of water purification from general organic pollution had an increase of 40 to $50 \%$. Stabile deodorization of water was achieved as well as absence of ozone treatment by-products (formaldehydes).

Open water sources in Western Europe suffer much greater technological assignment, thus AC must have a higher total organic carbon (DOC) adsorbing capability. Within the framework of Russian-German international project a new mark of AC named "Hydrosorb UK" was developed and tested at OJSC "Sorbent" (Perm). The AC has an adsorbing capability of $24 \mathrm{mg} / \mathrm{l}$ in accordance with DOC $(C=1.0 \mathrm{mg} / \mathrm{l})$. Such results were achieved due to utilization of $100 \% \mathrm{SS}$ rock carbon and lowering pellets' heating rate during pelletizing to 12 to $20^{\circ} \mathrm{C} / \mathrm{min}$.

"Hydrosorb UK" AC was loaded and tested at Hosterwiz waterworks (Dresden). It was clear that it absolutely complies with DIN-EN 12915 requirements and exceeds the sample ROW 08S (Netherlands) in multiple respects, which is shown in Table 2

Table 2

Iodine number, DOC adsorption ability and concentration in water of the studied AC

\begin{tabular}{|c|c|c|c|c|}
\hline \multirow{2}{*}{ Active carbon } & \multirow{2}{*}{$\begin{array}{c}\text { Iodine } \\
\text { number, } \\
\mathrm{mg} / \mathrm{g}\end{array}$} & \multirow{2}{*}{$\begin{array}{c}\text { DOC adsorption ability } \\
(\mathrm{C}=1,0 \mathrm{mg} / \mathrm{l}), \mathrm{ml} / \mathrm{g}\end{array}$} & \multicolumn{2}{|c|}{ Concentration in water, micg/1 } \\
\cline { 4 - 5 } & 820 & 16,0 & 1,2 -cis-dichloroethene & 1,2 - cis-dichloroethane \\
\hline Hydrosorb-5 & 850 & 24,0 & $<0,1$ & $<0,1$ \\
\hline Hydrosorb -UK & 1000 & 12,0 & $<0,1$ & $<0,1$ \\
\hline ROW08S (sample) & - & $<0,1$ & $<0,1$ \\
\hline DIN-EN 12915 & $>600$ & & $<0,1$ & $<0,1$ \\
\hline
\end{tabular}

The part in life of a modern population centre played by household post-treatment water filters is of great importance and not only in Russia but, literally, in the whole world. Such devices allow to after-extract micro-amounts of toxic organics completely preventing it from entering human tissues. Therefore, individual, as well as collective filters can be used.

One of the major researches produced upon conversion of manufacture of AC for gas masks is the creation of adsorbers for gold hydrometallurgy. By optimizing the solutions of the basis (50-70\% of rock carbon and $30-50 \%$ of half-coke) and of the binding agent (a mixture of coal and wood-chemical resins) the production technology for AG-90 mark AC was developed, and technology for producing AG-95 mark AC was developed by modifying the binding agent with phosphoric acid. Their performance meets OJSC "IRGIREDMET"'s requirements and reaches the level of foreign sorbents (see Table 3). 
This research is both of ecological and economical importance. It is well known that old gravitational technologies of gold mining brought harm upon the nature, but new hydrometallurgy technologies that utilize AC represent closed systems. Carbon demand of this market in Russia is presumed to be in the range of 1500 to 3000 tons a year.

Table 3

Characteristics of domestically produced and foreign AC for precious metals extraction (the data is available from OJSC "IRGIREDMET")

\begin{tabular}{|l|c|c|c|}
\hline \multicolumn{1}{|c|}{ AC mark } & $\begin{array}{c}\text { GOST hardness } \\
16188-70, \%\end{array}$ & Gold activity, mg /g & Leftovers mg/l \\
\hline FAS & 98,4 & 17,6 & 1,3 \\
\hline AG-90 & $85-88$ & 12,2 & 1,1 \\
\hline AG-95 & $88-90$ & 18,0 & 1,1 \\
\hline VKS-500 & 87,6 & 17,5 & 1,1 \\
\hline Taiko GW 612 (Japan) & 91,5 & 19,6 & 1,3 \\
\hline Chemviron FFW-A (USA) & 88,6 & 14,4 & 1,3 \\
\hline Norit R-2520 (Holland) & 88,0 & 25,8 & 1,3 \\
\hline Jx-102 (China) & 89,0 & 13,5 & 1,3 \\
\hline
\end{tabular}

Solid binding agent application (use of coal and wooden pitches) allows creating the most perspective technology of AC production, utilized by Chemviron Calgon (Belgium) and Calgon Carbon Corp. (USA). Such carbons are of wide spectrum of application in adsorbing technologies, first of all in water conditioning and treatment of waste and technological solutions.

One of the most progressive technologies is mixed activation, when carbon-containing material of low stage of metamorphism (peat, lignite or cannel coal) is used along with special chemical modifiers. These AC provide very high adsorption capabilities (see Table 4).

Table 4

Quality indices and structural parameters of carbon adsorbers

\begin{tabular}{|l|c|c|c|}
\hline \multicolumn{1}{|c|}{ Indices } & $\begin{array}{c}\text { Lignite } \\
\text { BKS }\end{array}$ & $\begin{array}{c}\text { Peat } \\
\text { TKS }\end{array}$ & $\begin{array}{c}\text { Long flame carbon } \\
\text { DKS }\end{array}$ \\
\hline 1.Apparent density, $\mathrm{g} / \mathrm{dm}^{3}$ & 320 & 290 & 340 \\
\hline 2. Hardness, $\%$ & 70 & 65 & 75 \\
\hline 3. Ash level, \% & 14 & 16 & 121 \\
\hline 4. Interstice capacity, $\mathrm{cm}^{3} / \mathrm{gr}$ & & & 0,80 \\
\hline$\bullet \quad \mathbf{V}_{\text {mi }}$ & 0,75 & 0,65 & 0,22 \\
\hline $\mathbf{V}_{\text {me }}$ & 0,25 & 0,25 & 0,13 \\
\hline $\mathbf{V}_{\text {ma }}$ & 0,30 & 0,30 & 1,15 \\
\hline $\mathbf{V}_{\Sigma}$ & 1,30 & 1,20 & 120 \\
\hline 5. Adsorption activity & & & \\
\hline Iodine, \% & 115 & 105 & 395 \\
\hline Methylene blue, $\mathrm{mg} / \mathrm{g}$ & 385 & 360 & \\
\hline
\end{tabular}

High technologies of the present century (circuit boards, electronics, life support systems, etc.) as well as endoecology of humankind will require especially pure carbons with ash admixture content below $0,1 \%$ of mass and ultrahigh durability. Thus there is no way of avoiding the usage of polymeric materials during the production of AC. The most preferable materials for AC production are phenol-formaldehyde resin (FTD mark), polyvinylidene chloride (PAU type carbons) and furfural copolymers (FAS).

Having no equals in this respect, FAS adsorbent is produced on the basis of furfural, using the simplest technological scheme comprising polymerization, gelatinization, and condensation. It's exploiting characteristics regarding industry (durability $-7000 \mathrm{~kg} / \mathrm{cm}^{2}$ ) and medicine (ash admixture content $-0,01 \%$ of mass) speak of a great investment potential.

Hydrometallurgy processes of nonferrous and precious metals mining, for the most part of gold, using FAS might lead to a technological revolution in that strategic industry. It has no matches amongst other carbons used in hydrometallurgy (see Table 3).

Utilization of AC in pharmaceutical industry is extremely significant. I would willingly put stress on the simple fact that gemo-sorption and entero-sorption based on AC literally protect people from lethal dangers. In 1814 in order to 
show marvellous properties of AC to full extent French monk Bertrand swallowed some arsenic oxide and an adequate portion of $\mathrm{AC}$ in series and remained alive. Another even more astonishing experiment was performed by apothecary Turey of Montpelier in 1834. He took a tenfold draught of the most lethal poison strychnine and an aliquot amount of AC. As in the previously mentioned example his experiment was a success. In 1948 German scientist Schmidt proved that active AC can absorb up to $100 \%$ of microbes from diluted culture of infectious bacteria in 10 minutes' time. At the present moment dozens of diseases from allergy to narcotism are cured thanks to gemo-sorption and entero-sorption (see "Entero-sorption" of professor N. Belaev).

One very special kind of food industry sorbents based upon shells and fruit pits is seen fulfilled at OJSC "NPO "Neorganika" experimental factory. Properties of AC domestically produced out of pits material, are shown in Tab. 5.

Table 5

Quality indices and structural parameters of active carbons made of pits material

\begin{tabular}{|c|c|c|c|c|c|c|}
\hline \multirow[b]{2}{*}{ Indices } & \multicolumn{3}{|c|}{ Pit of fruit trees } & \multicolumn{3}{|c|}{$\operatorname{coco}$} \\
\hline & MeKS & $\mathrm{AKU}$ & $\begin{array}{c}\text { MeKS } \\
\text { enterosorbent }\end{array}$ & VSK & VSK-V & VSK-A \\
\hline 1.Apparent density, $\mathrm{g} / \mathrm{dm}^{3}$ & 400 & $400-450$ & $380-390$ & 530 & 450 & 380 \\
\hline 2. Hardness, $\%$ & 91 & 93 & 86 & 92 & 90 & 85 \\
\hline 3. Ash level, $\%$ & 1,0 & 5,0 & 0,1 & 5,0 & 5,6 & 6,8 \\
\hline \multicolumn{7}{|l|}{ 4. Interstice capacity, $\mathrm{cm}^{3} / \mathrm{gr}$} \\
\hline - $\mathbf{V}_{\mathrm{mi}}$ & 0,510 & 0,390 & 0,620 & 0,325 & 0,420 & 0,580 \\
\hline - $\mathbf{V}_{\mathrm{me}}$ & 0,110 & 0,120 & 0,240 & 0,120 & 0,140 & 0,200 \\
\hline - $\mathbf{V}_{\mathrm{ma}}$ & 0,200 & 0,225 & 0,145 & 0,110 & 0,200 & 0,160 \\
\hline - $\mathbf{V}_{\Sigma}$ & 0,820 & 0,735 & 1,05 & 0,555 & 0,750 & 0,940 \\
\hline \multicolumn{7}{|l|}{ 5. Adsorption activity: } \\
\hline Iodine, $\%$ & 120 & 80 & 126 & 60 & 85 & 110 \\
\hline Methylene blue, mg/g & 315 & 225 & 350 & 140 & 185 & 340 \\
\hline
\end{tabular}

Implementation of such AC produces outstanding results in production of vodka, especially when AC block filter systems are used.

In the future, large scale implementation of $\mathrm{AC}$ will be required by the modern field of sorption technologies (e.g. soil detoxication, production of ecologically clean food). This means that the demand for "Agrosorb" class AC will only rise. Treatment of pesticide polluted soil with "Agrosorb" AC, utilizing from 50 to $200 \mathrm{~kg}$ of AC per hectare, allows not only to lift crop capacity of various crops but to ensure the harvest that would guarantee the production of ecologically clean food (see Tables 6,7 ).

Table 6

Harvest of crops on herbicidal background after using active carbon (50 kg/hectare norm).

\begin{tabular}{|l|c|c|c|c|}
\hline Crop & $\begin{array}{c}\text { Herbicidal background } \\
\text { and doses (kg/hectare) }\end{array}$ & $\begin{array}{c}\text { Harvest on herbicidal } \\
\text { background (centner/ } \\
\text { hectare) }\end{array}$ & $\begin{array}{c}\text { Harvest after using AC } \\
\text { (centner/hectare) }\end{array}$ & $\begin{array}{c}\text { Harvest increase } \\
\text { (centner/hectare, \%) }\end{array}$ \\
\hline Maize & Treflan, 1,4 & 53 & 78 & $25(47)$ \\
\hline Tomato & The same & 333 & 652 & $319(96)$ \\
\hline White beet & The same & 343 & 416 & $73(21)$ \\
\hline Rice & Ronstar, 2,0 & 60 & 72 & $12(20)$ \\
\hline Bulb onion & Ramrod, 8,5 & 228 & 295 & $67(29)$ \\
\hline Cucumber & Treflan, 1,0 & 85 & 202 & $117(138)$ \\
\hline Soy & Dialen, 9,0 & 11 & 49 & $6(14)$ \\
\hline Winter wheat & Unidentified remainder & 43 & 592 & $250(73)$ \\
\hline Maize* & The same & 342 & 85 & $22(35)$ \\
\hline Rice* & The same & 63 & & $13)$ \\
\hline
\end{tabular}

* The normal amount of AC was $100 \mathrm{~kg} /$ hectare. 
Assemblage of treflan and 2,4-D herbicides by crops.

\begin{tabular}{|c|c|c|c|}
\hline $\begin{array}{c}\text { Herbicide and it's dose } \\
(\mathrm{kg} / \mathrm{hectare})\end{array}$ & $\begin{array}{c}\text { Normal amount of AC (kg/ } \\
\text { hectare) }\end{array}$ & Test-crop & $\begin{array}{c}\text { Herbicide content in } \\
\text { harvest }(\mathrm{mkg} / \mathrm{kg})\end{array}$ \\
\hline Treflan, 1,0 & - & tomato & 28,0 \\
\hline$-\ll-$ & 100 & $-\ll-$ & 0,6 \\
\hline Treflan, 1,0 & - & carrot & not detected \\
\hline$-\ll-$ & $-\ll-$ & barley & not detected \\
\hline $2,4-\mathrm{D}$ & 200 & $-\ll-$ & 670 \\
\hline$-\ll-$ & - & barley & not detected \\
\hline $2,4-\mathrm{D}$ & 200 & $-\ll-$ & \\
\hline$-\ll-$ & & & \\
\hline
\end{tabular}

Incidentally, after completion of works on "Agrosorb" in the Krasnodar Territory in 1989 regional agroindustry department of Kuban purchased annual supply of 25 thousand tons of "Agrosorb" per year.

The area of utilization of such sorbents is larger than just agricultural holdings. It's the protection of open sources of water that serve as water-supply for cities, blocking of sewage from dumps and military testing areas, preservation of biological resources of reservoirs etc.

One of the most significant areas of utilization of agricultural AC is the detoxication of fodder in broiler poultry keeping, cattle breeding, pig-breeding etc., as they rise the safety of livestock and lowers the cost in fodder of a unit of weight of produce. The results of utilization of "Ptitsesorb" AC in broiler poultry keeping are shown in Table 8.

Table 8

The effectiveness of "Ptitsesorb" AC in detoxication of fodder in broiler poultry keeping.

\begin{tabular}{|l|c|c|}
\hline \multicolumn{1}{|c|}{ Groups } & Safety of livestock (\%) & $\begin{array}{c}\text { Cost in fodder of a unit } \\
\text { of weight of produce }(\mathrm{kg})\end{array}$ \\
\hline OR $+8 \mathrm{mkg} / \mathrm{kg}$ of $\mathrm{T}-2$ toxin & 72 & 2,73 \\
\hline $\begin{array}{l}\text { OR }+8 \mathrm{mkg} / \mathrm{kg} \text { of } \mathrm{T}-2 \text { toxin }+0,5 \% \\
\text { mass of AC }\end{array}$ & 92 & 2,57 \\
\hline
\end{tabular}

Presently, about 500 thousand tons of AC is produced in the whole world but, the main showings are rates of production and of use of AC per each man a year. In the Soviet Union the norm was $0,15 \mathrm{~kg} / \mathrm{man}$, and in the Republic of Russian Federation it's only 0,02 to $0,05 \mathrm{~kg} / \mathrm{man}$. In the meantime in the USA, Japan, and Western Europe countries this showing is about $0,5 \mathrm{~kg} / \mathrm{man}$. And in Holland that is situated at mouth of the Rhine the rate is $2,5 \mathrm{~kg} / \mathrm{man}$.

Reasoning from these numbers, Holland produces 40 thousand tons of AC per year. The People's Republic of China requires 500 tons of AC per year, thus they are vigorously developing their production capacities. Therefore, Russia has to produce 75 thousand tons of $\mathrm{AC}$ a year.

Russia has always been at the forefront of developing high-quality active carbons, catalysts and chemical absorbers based on AC. And, although we occupy 7-8 position amongst the producers of AC, the superiority of Russian $\mathrm{AC}$ is internationally recognized.

The direction of developing the production of AC for ecology is quite plain for specialists. We, from our own part, are open towards cooperative activities with our investors who are to gain not only considerable profits but also the worldwide recognition and appreciation of their part in preserving ecological safety and defending our Earth from ecocide.

\section{References}

[1] Mukhin V.M., Tarasov A.V., Klushin V.I. Active Carbons of Russia - Metallurgy, 2000 - 352 p.

[2] Kienle H., Bader E. Activated carbons and their industrial utilization. Ferdinand Enke Verlag Stuttgart, 1980, 316 p.

[3] Kawamura S.: Integrated design of water treatment facilities. J. Wiley\&sons, Inc., 1991, 658 p.

[4] Lupascu T.: Activated carbons obtained from vegetal raw materials. "Stiinta", Chisinau, 2004,224 p.

[5] Giordano C.: Sorbents and their clinical applications, Academic Press, 1980, 400 p.

[6] Nikolaev V.: The method of hemoperfusion in experimental and clinical trials. "Naukova dumka", Kiev, 1984, 360 . 